\title{
Mengenal Teori Kultivasi dalam Ilmu Komunikasi
}

\section{Cultivation Theory in Communication Science}

\author{
Junaidi \\ Program Studi Pemikiran Politik Islam, \\ Universitas Islam Negeri Sumatera Utara, Indonesia \\ *Corresponding Author, Email: Jun_abu_ihda@yahoo.com
}

\begin{abstract}
Abstrak
Teori kultivasi memusatkan perhatian pada dampak menonton tayangan televisi pada perilaku penonton televisi dalam jangka waktu yang panjang. Teori ini beranggapan bahwa manusia yang selalu menonton tayangan tertentu dengan waktu yang lama maka akan memiliki sebuah pemahaman bahwa dunia di sekelilingnya seperti yang ditayangkan di televisi. Misalnya saja seseorang yang selalu menonton acara-acara yang mengandung tayangan kekerasan (baik film maupun berita) dengan durasi lama dan frekuensi yang sering, maka akan memiliki pola pikir bahwa perilaku kekerasan seperti yang ditunjukkan di televisi mencerminkan kejadian di sekitarnya. Kekerasan yang dipresentasikan di televisi dianggap sebagai kekerasan yang terjadi di dunia.
\end{abstract}

Kata Kunci: Teori Kultivasi, Ilmu Komunikasi.

\begin{abstract}
Cultivation theory focuses on the impact of television viewing on the behavior of television viewers over a long period of time. This theory assumes humans who always watch the impressions with a long time it will have an understanding of the world around it as shown on television. For example, someone who always watches events that contain violent impressions (both movies and news) with long duration and frequent frequencies, it will have a mindset like that happen on television otherwise the events around it. The violence presented on television is the violence that occurs in the world.

Keyword: Cultivation Theory, Communication Science
\end{abstract}

How to Cite: Junaidi, (2018), Teori Kultivasi dalam Ilmu Komunikasi, SIMBOLIKA, 4 (1): 42-51. 


\section{PENDAHULUAN}

Teori Kultivasi ini adalah teori tentang penanaman, atau bisa juga disebut dengan penyuburan. Gagasan tentang cultivation theory atau teori kultivasi untuk pertama kalinya dikemukakan oleh George Gerbner bersama dengan rekan-rekannya tahun 1969 . Joseph A. Devito, Komunikasi Antar Manusia; Kuliah Dasar Edisi Kelima. (Jakarta: Professional Books, 1997), h. 527 Goeorge Gerbner merupakan Dekan emiritus dari Annenberg School for Communication di Universitas Pensylvania. Sebagai seorang imigran dari Hongaria yang mempunyai profesi penulis, ia kemudian masuk sekolah Jurnalistik pada Universitas Berkely. Setelah lulus Bachelor (S1) ia bekerja di San Fransisco Chronicle. Kemudian kembali ke kampusnya untuk mengambil Program Masters dan Doctoral (Ph.D). Riset pertamanya pada awal tahun 1960-an tentang Proyek Indikator Budaya (Cultural Indicators Project) untuk mempelajari pengaruh menonton televise (Severin dan Tankard, 2001: 268).

Awalnya, Gerbner melakukan penelitian tentang "Indikator Budaya" dipertengahan tahun 60-an untuk mempelajari pengaruh menonton televisi. Dengan kata lain, Gerbner ingin mengetahui dunia nyata seperti apa yang dibayangkan, dipersepsikan oleh penonton televisi itu? Itu juga bisa dikatakan bahwa penelitian kultivasi yang dilakukannya lebih menekankan pada "dampak" . (Nurudin, 2004: 157). Menurut Wood, kata 'cultivation' sendiri merujuk pada proses kumulatif dimana televisi menanamkan suatu keyakinan tentang realitas sosial kepada khalayaknya (Wood, 2000: 87).

Teori kultivasi muncul dalam situasi ketika terjadi perdebatan antara kelompok ilmuwan komunikasi yang meyakini efek sangat kuat media massa (powerfull effects model) dengan kelompok yang mempercayai keterbatasan efek media (limited effects model), dan juga perdebatan antara kelompok yang menganggap efek media massa bersifat langsung dengan kelompok efek media massa bersifat tidak langsung atau kumulatif. Teori kultivasi muncul untuk meneguhkan keyakinan orang, bahwa efek media massa lebih besifat kumulatif dan lebih berdampak pada tataran sosial-budaya ketimbang individual.

Menurut Signorielli dan Morgan analisis kultivasi merupakan tahap lanjutan dari paradigma penelitian tentang efek media, yang sebelumnya dilakukan oleh George Gerbner yaitu 'cultural indicator' yang menyelidiki: a) proses institusional dalam produksi isi media, b) image (kesan) isi media, dan c) hubungan antara terpaan pesan televisi dengan keyakinan dan perilaku khalayak. (Griffin, 2004: 210).

Teori kultivasi ini di awal perkembangannya lebih memfokuskan kajiannya pada studi televisi dan audience, khususnya pada tema-tema kekerasan di televisi. Tetapi dalam perkembangannya, ia juga bisa digunakan untuk kajian di luar tema kekerasan. Misalnya, seorang mahasiswa Amerika di sebuah universitas pernah mengadakan pengamatan tentang para pecandu opera sabun (heavy soap opera). Mereka, lebih memungkinkan melakukan affairs (menyeleweng), bercerai dan menggugurkan kandungan dari pada mereka yang bukan termasuk kecanduan opera sabun.

Gerbner bersama beberapa rekannya kemudian melanjutkan penelitian media massa tersebut dengan memfokuskan pada dampak media massa dalam kehidupan sehari-hari melalui Cultivation Analysis. Dari analisis tersebut diperoleh berbagai temuan yang menarik dan orisional yang kemudian banyak mengubah keyakinan orang tentang relasi antara televisi dan khalayaknya berikut berbagai efek yang menyertainya. Karena konteks penelitian ini dilakukan dalam kaitan merebaknya acara kekerasan di televisi dan meningkatnya angka kejahatan di masyarakat, maka temuan penelitian ini lebih terkait efek kekerasan di media televisi terhadap persepsi 
khalayaknya tentang dunia tempat mereka tinggal.

Salah satu temuan terpenting adalah bahwa penonton televisi dalam kategori berat (heavy viewers) mengembangkan keyakinan yang berlebihan tentang dunia sebagai tempat yang berbahaya dan menakutkan. Sementara kekerasan yang mereka saksikan ditelevisi menanamkan ketakutan sosial (sosial paranoia) yang membangkitkan pandangan bahwa lingkungan mereka tidak aman dan tidak ada orang yang dapat dipercaya. Gerbner berpendapat bahwa media massa menanamkan sikap dan nilai tertentu. Media pun kemudian memelihara dan menyebarkan sikap dan nilai tersebut antar anggota masyarakat, kemudian mengiktannya bersama-sama pula. Media mempengaruhi penonton dan masing-masing penonton itu menyakininya. Jadi, para pecandu televisi itu akan punya kecenderungan sikap yang sama satu sama lain.

Secara keilmuan untuk menunjukan bahwa televisi sebagai media yang mempengaruhi pandangan kita terhadap realitas sosial, para peneliti cultivation analysis bergantung kepada empat tahap proses: a) Message system analysis yang menganalisis isi program televise; b) Formulation of question about viewers' sosial realities yaitu pertanyaan yang berkaitan dengan seputar realitas sosial penonton televise; c) Survey the audience yaitu menanyakan kepada mereka seputar apa yang mereka konsumsi dari media; dan d) Membandingkan realitas sosial antara penonton berat dan orang yang jarang menonton televisi.

Keempat tahap ini dapat disederhanakan menjadi dua jenis analisis: a) analisis isi (content analysis), yang mengidentifikasikan atau menentukan tematema utama yang disajikan oleh televise; dan b) Analisis khalayak (audience research), yang mencoba melihat pengaruh tema-tema tersebut pada penonton. Langkah utama untuk menguji teori kultivasi dalam studi awal adalah menentukan kandungan isi televisi melalui analisis isi. Gerbner dan kawan-kawan mulai memetakan kandungan isi pada prime time dan program televisi bagi anak-anak diakhir pekan (weekend).

Di antara berbagai teori dampak media jangka panjang, cultivation analysis merupakan teori yang menonjol. Gerbner menyatakan bahwa televisi sebagai salah satu media modern, telah memperoleh tempat sedemikian rupa dan sedemikian penting dalam kehidupan sehari-hari masyarakat, sehingga mendominasi "lingkungan simbolik" kita dengan cara menggantikan pesannya tentang realitas bagi pengalaman pribadi dan sarana mengetahui dunia lainnya. Teori kultivasi melihat media massa sebagai agenda sosialisasi, dan menemukan bahwa penonton televisi dapat mempercayai apa yang ditampilkan oleh televisi berdasarkan seberapa banyak mereka menontonnya.

Berdasarkan banyaknnya waktu yang dihabiskan untuk menonton, maka penonton televisi dikelompokkan dalam dua kategori yakni light viewer (penonton ringan dalam arti menonton rata-rata dua jam perhari atau kurang dan hanya tayangan tertentu) dan heavy viewer (penonton berat), menonton rata-rata empat jam perhari atau lebih dan tidak hanya tayangan tertentu. Infante et.all, Building Communication Theory. (Grove, 2003: 65).

\section{PEMBAHASAN}

Asumsi pertama menyatakan bahwa televisi merupakan media yang unik. Keunikan tersebut ditandai oleh karakteristik televisi yang bersifat: a) Pervasive (menyebar dan hampir dimiliki seluruh keluarga); b) Assesible (dapat diakses tanpa memerlukan kemampuan literasi atau keahlian lain), dan c) Coherent (mempersentasikan pesan dengan dasar yang sama tentang masyarakat melintasi program dan waktu). 
Semakin banyak seseorang menghabiskan waktu untuk menonton televisi, semakin kuat kecenderungan orang tersebut menyamakan realitas televisi dengan realitas sosial. Jadi menurut asumsi ini, dunia nyata (real world) di sekitar penonton dipersamakan dengan dunia rekaan yang disajikan media tersebut (symbolic world). Dengan bahasa yang lebih sederhana dapat dikatakan bahwa penonton mempersepsi apapun yang disajikan televisi sebagai kenyataan sebenarnya. Namun teori ini tidak menggeneralisasi pengaruh tersebut berlaku untuk semua penonton, melainkan lebih cenderung pada penonton dalam kategori heavy viewer (penonton berat).

Hasil pengamatan dan pengumpulan data yang dilakukan oleh Gerbner dan kawankawan bahkan kemudian menyatakan bahwa heavy viewer mempersepsi dunia ini sebagai tempat yang lebih kejam dan menakutkan (the mean and scray world) ketimbang kenyataan sebenarnya. (McQuail, 2001: 465). Fenomena inilah yang kemudian dikenal sebagai "the mean world syndrome" (sindrom dunia kejam) yang merupakan sebentuk keyakinan bahwa dunia sebuah tempat yang berbahaya, sebuah tempat di mana sulit ditemukan orang yang dapat dipercaya, sebuah tempat di mana banyak orang di sekeliling kita yang dapat membahayakan diri kita sendiri. Untuk itu orang harus berhati-hati menjaga diri. Pembedaan dan pembandingan antara heavy dan light viewer di sini dipengaruhi pula oleh latar belakang demografis di antara mereka.

Penonton ringan (light viewers) cenderung menggunakan jenis media dan sumber informasi yang lebih bervariasi (baik komunikasi bermedia maupun sumber personal), semantara penonton berat (heavy viewers) cenderung mengandalkan televisi sebagai sumber informasi mereka. Asumsi ini menyatakan, kelompok penonton yang termasuk kategori berat, umumnya memiliki akses dan kepemilikan media yang lebih terbatas. Karena itu mereka mengandalkan televisi sebagai sumber informasi dan hiburan mereka. Karena keterpakuan pada satu media ini, membuat keragaman dan alternatif informasi yang mereka miliki menjadi terbatas. Itulah sebabnya kemudian mereka membentuk gambaran tentang dunia dalam pikirannya sebagaimana yang digambarkan televisi. Sebaliknya kelompk light viewers memiliki akses media yang lebih luas, sehingga sumber informasi mereka menjadi lebih variatif. Karena kenyataan ini, maka pengaruh televisi tidak cukup kuat pada diri mereka.

Menurut teori ini, media massa khususnya televisi diyakini memiliki pengaruh yang besar atas sikap dan perilaku penontonnya (behavior effect). Pengaruh tersebut tidak muncul seketika melainkan bersifat kumulatif dan tidak langsung. Inilah yang membedakan teori ini dengan The Hypodermic Needle Theory, atau sering juga disebut The Magic Bullet Theory, Agenda Setting Theory, Spiral of Silence Theory. Lebih lanjut dapat dikemukakan bahwa pengaruh yang muncul pada diri penonton merupakan tahap lanjut setelah media itu terlebih dahulu mengubah dan membentuk keyakinankeyakinan tertentu pada diri mereka melalui berbabagai acara yang ditayangkan. Satu hal yang perlu dicermati adalah bahwa teori ini lebih cenderung berbicara pengaruh televisi pada tingkat komunitas atau masyarakat secara keseluruhan dan bukan pada tingkat individual. Secara implisit teori ini juga berpendapat bahwa pemirsa televisi bersifat heterogen dan terdiri dari individu-individu yang pasif yang tidak berinteraksi satu sama lain. Namun mereka memiliki pandangan yang sama terhadap realitas yang diciptakan media tersebut.

Terpaan pesan televisi yang terus menerus menyebabkan pesan tersebut diterima khalayak sebagai pandangan konsensus masyarakat. Asumsi keempat toeri ini menyatakan bahwa terpaan televisi yang intens dengan frekuensi yang kerap dan terus 
menerus membuat apa yang ada dalam pikiran penonton televisi sebangun dengan apa yang disajikan televisi. Karena alasan ini kemudian mereka menganggap bahwa apapun yang muncul di televisi sebagai gambaran kehidupan sebenarnya, gambaran kehidupan yang disepakati secara konsensual masyarakat. Dalam konteks ini berarti, bila penonton melihat orang sumpah pocong di televisi, atau melihat adegan ciuman di antara dua orang yang masih pacaran dalam sebuah sinetron maka penonton tersebut menganggap hal itu sesuatu hal yang lumrah saja yang menganggap kehidupan nyata di lingkungannya.

Televisi membentuk mainstreaming dan resonance, adalah asumsi kelima yang menegaskan bahwa televisi membentuk mainstreaming dan resonace. Gerbner dan kawan-kawan memperkenalkan faktor-faktor mainstreaming dan resonance. Mainstreaming diartikan sebagai kemampuan memantapkan dan menyeragamkan berbagai pandangan di masyarakat tentang dunia di sekitar mereka (TV stabilize and homogenize views within a society). Dalam proses ini televisi pertama kali akan mengaburkan (bluring), kemudian membaurkan (blending) dan melenturkan (bending) perbedaan realitas yang beragam menjadi pandangan mainstream tersebut. Sedangkan resonance mengimplikasikan pengaruh pesan media dalam persepsi realita dikuatkan ketika apa yang dilihat orang di televisi adalah apa yang mereka lihat dalam kehidupan nyata.

Perkembangan teknologi baru memperkuat pengaruh televise, adalah asumsi terakhir yang menyatakan bahwa perkembangan teknologi baru memperkuat pengaruh televisi. Asumsi ini diajukan Gerbner pada tahun 1990 setelah menyaksikan perkembangan teknologi komunikasi yang luar biasa. Asumsi ini mengandung keyakinan bahwa teknologi pendukung tidak akan mengurangi dampak televisi sebagai sebuah media, malahan pada kanyataannya akan meneguhkan dan memperkuat.

Bukti utama asumsi cultivation analysis berasal dari analisis isi pesan televisi Amerika secara sistematis. Analisis itu dilakukan selama beberapa tahun dan menunjukan distorsi realitas yang konsisten dalam hubungannya dengan keluarga, pekerjaan dan peran, usia lanjut, mati dan kematian, pendidikan, kekerasan dan kejahatan. Isu ini memberikan pelajaran tentang hal-hal yang diharapkan dari kehidupan bukanlah pesan yang membesarkan hati, khususnya bagi si miskin, kaum wanita dan minoritas rasial (McQuail, 2001: 254). Jadi, meskipun televisi bukanlah satu-satunya sarana yang membentuk pandangan kita tentang dunia, televisi merupakan salah satu media yang paling ampuh, terutama bila kontak dengan televisi yang sangat sering dan berlangsung dalam waktu lama (Ardianto dkk, 2004: 65).

Teori kultivasi sering digunakan untuk menganalisis berbagai bentuk praktik komunikasi, terutama komunikasi massa khususnya televisi. adapun yang kita kita kenal dengan istilah cultivation analysis. Studi yang dilakukan oleh Nancy Signorielli (John, 2005: 289). Ia melaporkan tentang sindrom dunia kejam. Pada aksi kekerasan di program televisi bagi anak, lebih dari 2000 program termasuk 6000 karakter utama selama prime time dan akhir pekan (weekend) dari tahun 1967-1985, menganalisis dengan hasil yang menarik, $70 \%$ prime time dan $94 \%$ akhir pekan (weekend) termasuk aksi kekerasan. Analisis ini membuktikan bahwa heavy viewers memandang dunia muram dan kejam dibandingkan dengan orang yang jarang menonton televisi. Tidak salah jika kemudian Gerbner dan kawan-kawan melaporkan bahwa heavy viewers melihat dunia lebih kejam dan menakutkan seperti yang ditampilkan televisi dari pada orang-orang yang jarang menonton.

Penelitian yang dilakukan oleh Dadi Ahmadi dan Nova Yohana pada tahun 2005 
dengan judul "Kekerasan di Televisi; Perspektif Kultivasi”. Dalam Penelitiannya ini, mereka menggunakan Teori Kultivasi sebagai landasan/acuan berpikirnya. Hasil penelitian mereka menyebutkan bahwa tayangan kriminalitas sudah menjadi menu harian Televisi. Tak Kurang dari 8 program televisi yang bertema kriminalitas dalam bentuk berita, adalagi dalam bentuk sinetron dan ditambah lagi tayangan kekerasan dalam bentuk iklan produk. Semua tayangan tersebut pada akhirnya dapat membangun pemikiran penonton televisi beranggapan bahwa dunia ini kejam dan penuh kekerasan. (Ahmadi dan Nova, 2005: 91)

Penelitian yang dilakukan oleh Ivan Ibnu Salam pada tahun 2012 dengan judul "Hubungan Antara Terpaan Drama Korea di Televisi dengan Gaya Hidup Penonton". Penelitian ini menggunakan teori kultivasi. Hasil penelitian menyebutkan bahwa dari 117 responden yang diteliti, sebanyak 90 terpengaruh gaya hidupnya dengan drama Korea yang mereka tonton. Artinya, ada hubungan antara gaya hidup dengan drama Korea yang mereka tonton. Adapun responden yang terpengaruh adalah mereka yang menonton tayangan Drama Korea selama 3 jam dalam sehari (Salam, 2012: 1).

Penelitian yang dilakukan oleh Yudhi Primadiansyah dengan judul "Pengaruh televisi Terhadap Perilaku Kekerasan" Penelitian ini menggunakan terori Kultivasi sebagai acuan dalam penelitiannya. Dalam karya nya dibahas tentang tayangan OVJ (Opera Van Java) yang di dalamnya banyak adegan kekerasan, misalnya mendorong pemain lain ke dinding atau assesoris lain yang terbuat dari bahan-bahan lunak, sehingga bahan tersebut hancur dalam rangka untuk mengundang gelaktawa dari penonton. Menurut Peneliti, tayangan seperti ini ternyata bisa membentuk perilaku keras dari para penontonnya. (Pramadiansyah, 2014: 22).

Penelitian yang dilakukan oleh Wataru dengan judul "Does Viewing Television Affect the Academic Performance of Childre" pada tahun 2012. Hasil kesimpulan penelitian tersebut menyebutkan bahwa Penelitian yang dilakukan, memberikan bukti bahwa menonton televisi memiliki dampak yang negatif terhadap kinerja anak di sekolah, meskipun kita tidak bisa mengabaikan kemungkinan instrument yang lemah. Penelitian yang dilakukan oleh Darius dengan judul "Changes in Diet and Lifestyle and LongTerm Weight Gain in Women and Men" pada tahun 2011. Adapun hasil penelitian tersebut adalah perubahan gaya hidup masyarakat dapat berubah karena menyaksikan televisi dengan nilai $\mathrm{P}<0.001$

Penelitian yang dilakuan oleh Mirra Noor Milla dengan judul "Pengaruh Terpaan Kekerasan Media Audio-Visual Pada Kognisi Agresif dan Afeksi Agresif Studi Meta Analisis. Penelitian ini dilakukan pada tahun 2009 dengan hasil terdapat hubungan antara terpaan kekerasan di media audio-visual dengan kognisi dan afeksi agresif. (Milla, 2009: 68).

Penelitian yang dilakukan oleh Devina Hermanto dengan judul "Pengaruh Tayangan Variety show Running Man di SBS terhadap perubahan perilaku (Studi pada anggota group fans Running Man Indonesia di Twitter). Penelitian ini dilakukan pada tahun dengan hasil Dapat diketahui bahwa tayangan variety show Running Man mempunyai 61,9\% pengaruh terhadap perubahan perilaku dan $38,1 \%$ dipengaruhi oleh tabel lain. Pengaruh waktu, pemain, lokasi, permainan merupakan salah satu penyebab perubahan perilaku fans Running Man di Indonesia. (Hermanto, 2011: 71).

Penelitian yang dilakukan oleh Alexander DA dengan judul "Pengaruh tayangan "Mujizat Itu Nyata" di RCTI terhadap Minat Beribadah Umat Kristiani (Studi Kasus pada Jemaat GBI Brilianti). Hasil penelitian ini adalah Nilai ini menunjukan bahwa pengaruh variabel $\mathrm{X}$ terhadap variabel $\mathrm{Y}$ adalah sebesar $34,3 \%$ dan besarnya variabel 
lain yang mempengaruhi varibel $\mathrm{X}$ di luar kasus ini adalah sebesar 65,7 \%. (Alexander, 2010: 59). Penelitian yang dilakukan oleh Rima Oktaviani pada tahun 2011 dengan judul "Hubungan Tayangan Reality Show "Be A Man di Global TV dengan Perilaku Asertif Transgender". Adapun hasil penelitian menyebutkan Meskipun hubungan antara terpaan tayangan reality show "Be A Man" di Global TV terhadap perilaku asertif transgender lemah, tapi mereka tetap menonton tayangan tersebut. Perilaku asertif mereka yang tinggi tidak memiliki korelasi yang kuat dengan terpaan tayangan, artinya ada kemungkinan perilaku asertif mereka dipengaruhi variabel lainnya. (Oktaviani, 2011: 61).

Penelitian yang dilakukan oleh Maria Frili dari Universitas Binus pada tahun 2015 dengan judul "Pengaruh Tayangan ILOOk di NET TV Terhadap MinatKreatifitasPenonton (Studi Pada Folloewrs Twitter". Hasil penelitian menyebutkan bahwa Berdasarkan perhitungan, $48 \%$ responden perempuan sebanyak 44 orang, dan 5 orang yang terpengaruh oleh tayangan "iLook" terhadap minat kreatifitas mereka. Mereka merasa tayangan "iLook" mendorong mereka untuk meningkatkan kreatifitas mereka dengan mencoba hal baru". (Frili, 2015: 59).

Penelitian yang diakukan oleh Amir Hetsroni dan Hila Lowenstein, dengan judul "Religiosity, Repression and Cultivation: Different Pattern of TV Viewing Effect on Crime Prevalence Estimates and Personal Victimization Likelihood Assessment", Adapun hasil penelitian menyebutkan Resiko personal untuk perampokan dengan kekerasan $13,6 \%$ untuk yang relogius dan $22,3 \%$ untuk non religius. Resiko personal untuk kriminalitas properti tanpa kekerasan sebesar 19,3\% untuk yang religi dan 28,6\% untuk non religius. Perkiraan kelaziman untuk perampokan dengan kekerasan sebesar $16,3 \%$ untuk yang religius dan 24,2\% non religius. Perkiraan kelaziman untuk kriminalitas properti tanpa kekerasan sebesar $21,8 \%$ untuk yang religi dan 30,5\% untuk non religius.

Penelitian yang dilakukan oleh Hanim padatahun 2009 dengan judul "Pengaruh Terpaan Berita Kejahatan di Televisi Terhadap Sikap Waspda dan Cemas Pada Ibu Rumah Tangga". Hasil penelitian menyebutkan bahwa berita kejahatan yang ditayangkan oleh SCTV dan ANTV berpengaruh terhadap pembentukan realitas sosial (Waspada dan Cemas) pada ibu-ibu rumah tangga. (Hamim, 2009: 37).

Penelitian yang dilakukan oleh Kasriani pada tahun 2014 dengan Judul "Dampak Tayangan Show Imah di Trans TV pada gaya Bicara Remaja di Desa Santan Ilir Kecamatan Marangkayu". Adapun Hasil Peneltiian menyebutkan bahwa: Pertama, "Dampak menonton tayangan talk show Show imah pada perilaku dalam gaya bicara remaja yaitu berdampak negatif, seperti adanya perilaku meniru adegan-adegan yang terkesan tidak sopan dalam hal gaya bicara yang ditampilkan dalam talk show Show imah yang meliputi aksi peniruan dalam hal gaya bicara, hal kata-kata (verbal) serta perilaku dalam gaya bicara itu juga dipengaruhi dua faktor yaitu faktor personal yang terdiri dari : faktor biologis, motif sosiogenis, sikap, dan kebiasaan. Faktor situasional terdiri dari: Suasana Perilaku (Behavioural setting) dan Tekonologi Komunikasi.

Kedua, Melalui beberapa uji teori komunikasi massa yang penulis gunakan dalam penelitian ini yaitu teori pembelajaran social, teori perilaku dan teori kultivasi yang telah teruji bahwa media massa dapat memberikan efek atau dampak yang kuat dan memberikan efek secara langsung kepada khalayaknya melalui tayangan-tayangan yang disuguhkan apalagi mengingat bahwa tayangan tersebut memiliki jam tayang setiap hari yang akan secara bebas memberikan efek secara langsung bagi 
responden yang menontonnya secara terus menerus baik efek negatif maupun efek positif.

Ketiga, Aspek peniruan yang dilakukan oleh remaja juga terdapat perbedaan jawaban dari informan, ada yang melakukan peniruan dan mempraktekkan gaya bicara itu karena memang suka dengan acara Show imah tersebut, untuk mencari identitas diri melalui gaya atau style penggunaan bahasa tapi ada juga yang mempraktekkan gaya bicara dari tayangan Show imah tersebut karena mengikuti gaya dan trend masa kini yang lagi fenomenal di kalangan masyarakat, dalam hal kata-kata (verbal), keseluruhan remaja yang menjadi informan cenderung ikut meniru dan mempraktekkan kata-kata yang ada dalam talk show tersebut kedalam kehidupan mereka sehari-hari, misalnya seperti saling mengucapkan kata-kata masalah buat loe, loe dan gue dengan tingkah yang konyol kepada sesama teman dan keluarga.

Keempat, Perilaku gaya bicara remaja dipengaruhi oleh dua faktor yaitu faktor personal yang terdiri dari: faktor biologis, motif sosiogenis, sikap, dan kebiasaan. Faktor situasional terdiri dari: Suasana Perilaku (Behavioural setting) dan Tekonologi Komunikasi (Kasriani, 2014: 231-244).

Meskipun teori kultivasi yang diperkenalkan oleh George Gerbner ini sudah tepat diterapkan pada analisis yang berkaitan dengan tayangan televisi, akan tetapi ada beberapa kelemahan dan kritik terhadap teori ini, antara lain: 1) Korelasi antar terpaan televisi dan kepercayaan khalayak membuktikan hubungan sebab akibat. Tayangan di televisi membentuk sebuha realitas sosial yang dibangun dengan cara teetentu, akan tetapi realitas sosial ini bisa jadi mempengaruhi prilaku. 2) Perilaku khalayak dan apa yang dilihat khalayak pasti banyak dipengaruhi oleh latar belakang sosial budaya. Sikap kita tidak hanya dipengaruhi oleh televisi saja, tetapi juga oleh media lain, pengalaman langsung orang lain, dan lain-lain. 3) Program televisi yang berbeda akan memberikan kontribusi yang berbeda dalam membentuk realitas. Maka letak kelemahan teori kultivasi adalah teori ini menganggap setiap tayangan televisi adalah homogen. Dalam kenyataannya ada banyak hal yang harus diperhatikan. Misalnya saja para heavy viewers seharusnya lebih memperhatikan penampilannya. Hal ini disebabkan biasanya aktor dan aktris di televisi kelihatan muda, langsing dan menarik. Tetapi kenyataannya para heavy viewers ini sama sekali tidak menaruh perhatian pada kesehatan dan berat badan. 4) Hubungan tayangan kekerasan di televisi dan rasa takut dapat dijelaskan melalui hubungan bertetangga dimana khalayak tinggal. Mereka yang tinggal di daerah yang tingkat kriminalitasnya tinggi cenderung untuk tetap tinggal di rumah dan meyakini bahwa ada kemungkinan besar dirinya akan diserang dibanding dengan mereka yang tinggal di daerah yang tingkat kriminalitasnya rendah. 5) Teori kultivasi tidak memperhatikan pentingnya dinamika sosial dari penggunaan televisi. Faktor-faktor seperti tingkat perkembangan, pengalaman, pengetahuan umum, gender, etnis, sikap keluarga dan latar belakang sosial ekonomi, memberikan kontribusi dalam menanggapi tayangan di televisi. Misalnya saja, kelompok dengan status sosial ekonomi yang rendah cenderung menonton televisi sebagai satu - satunya sumber informasi bila dibandingkan dengan kelompok lain.

\section{SIMPULAN}

Teori Kultivasi lahir dalam situasi ketika terjadi perdebatan antara kelompok ilmuwan komunikasi yang meyakini efek sangat kuat media massa (powerfull effects model) dengan kelompok yang mempercayai keterbatasan efek media (limited effects model), dan juga perdebatan antara kelompok yang menganggap efek media massa bersifat langsung dengan kelompok efek media massa bersifat tidak langsung atau kumulatif. Teori 
kultivasi muncul untuk meneguhkan keyakinan orang, bahwa efek media massa lebih besifat kumulatif dan lebih berdampak pada tataran sosial-budaya ketimbang individual. Ada 6 asumsi dasar teori ini, yaitu: Televisi merupakan media yang unik; Semakin banyak seseorang menghabiskan waktu untuk menonton televisi, semakin kuat kecenderungan orang tersebut menyamakan realitas televisi dengan realitas sosial; Penonton ringan (light viewers) cenderung menggunakan jenis media dan sumber informasi yang lebih bervariasi (baik komunikasi bermedia maupun sumber personal), semantara penonton berat (heavy viewers) cenderung mengandalkan televisi sebagai sumber informasi mereka; Terpaan pesan televisi yang terus menerus menyebabkan pesan tersebut diterima khalayak sebagai pandangan konsensus masyarakat; Televisi membentuk mainstreaming dan resonance. Dan Perkembangan teknologi baru memperkuat pengaruh televisi. Teori kultivasi ini banyak dipakai dalam penelitian oleh para peneliti yang ingin mengetahui dampak dari Televisi yang merupakan bentuk media massa. Walaupun secara umum tayangan televisi mampu mempengaruhi perilaku penonton sebagaimana yang disampaikan oleh teori ini, namun semua itu juga dipengaruhi oleh banyak faktor. Oleh sebab itu faktor-faktor lain itu perlu menjadi pertimbangan dalam membuat sebuah pernyataan bahwa perilaku khalayak tidak sepenuhnya dipengaruhi oleh tayangan yang ia tonton.

\section{DAFTAR PUSTAKA}

Ahmadi, D., dan Nova Y, (2005), Kekerasan di Televisi; Perspektif Kultivas, Jurnal Penelitian. Jakarta: Dirjen Dikti.

Alexander DA, (2010), Pengaruh tayangan "Mujizat Itu Nyata" di RCTI terhadap minar beribadah umat Kristiani; Studi kasus pada jemaat GBI Briliant, Skripsi, Jakarta: Universitas Bina Nusantara.
Ardianto, E., dan Lukiati K,E, (2004), Komunikasi Massa Suatu Pengantar. Bandung: Simbiosa Rekatama Media.

Devito, J.A., (1997), Komunikasi Antarmanusia Kuliah Dasar", Jakarta: Professional Books.

Dominick, J.R., (1990), The Dynamick of Mass Communication, New York: Random House.

Frili, M., (2015), Pengaruh Tayangan ILOOk di NET TV Terhadap Minat Kreatifitas Penonton; Studi Pada Folloewrs Twitter. Tesis, Universitas Bina Nusantara.

Griffin, E.A., (2004), A First Look At Communication Theory, New York: McGraw-Hill.

Hamim, (2009), Pengaruh Terpaan Berita Kejahatan di Televisi Terhadap Sikap Waspada dan Cemas Pada Ibu Rumah Tangga," dalam Jurnal Ilmu Komunikasi Volume 1 Nomor 1: 54

Hermanto, D., (2011), Pengaruh Tayangan Variety show Running Man di SBS terhadap perubahan perilaku; Studi pada anggota group fans Running Man Indonesia di Twitter", Skripsi, Jakarta: Uiversitas Bina Nusantara.

Infante, D.A., Andrew S., Rancer \& Deanna F.W., (2003), Building Communication Theory, Long Grove: Waveland Press.

Kasriani, (2014) "Dampak Tayangan Show Imah Di Trans TV Pada Gaya Bicara Remaja Di Desa Santan Ilir Kecamatan Marangkayu", Jurnal Ilmu Komunikasi. Samarinda: FISIP Universitas Mulawarman.

Littlejohn, S.W., (2005), Theories of Human Communication, Eighth Edition. Belmont: Wadsworth Publishing Company.

Mc Quail, D., (1987), Teori Komunikasi Massa, Edisi Kedua, Jakarta: Erlangga.

McQuail's, D., (2001), Mass Communication Theory, London. 4th edition: SAGE Publications, Inc.

Milla, M.N., (2009), Pengaruh Terpaan Kekerasan Media Audio-Visual Pada Kognisi Agresif dan Afeksi Agresif Studi Meta Analisis, Skripsi Jogjakarta: Universitas Gajah Mada.

Nurudin. (2004), Komunikasi Massa, Malang: Cespur.

Oktaviani, R., (2011), "Hubungan Tayangan Reality Show Be A Man di Global TV dengan Perilaku Asertif Transgender", Tesis, Universitas Bina Nusantara.

Pramadiansyah, Y., (2014), Pengaruh Televisi Terhadap Pembentukan Perilaku Kekerasan, Kumpulan Hasil Penelitian Tesis Jakarta: Uiniversitas Indonesia. 
SIMBOLIKA, 4 (1): 42-51.

Salam, I.I., (2012), Hubungan Antara Terpaan Drama Korea di Televisi dengan Gaya Hidup Penonto, Jurnal Mahasiswa, Volume 1, Nomor 1, Bandung: Universitas Padjadjaran.
Severin, W.J., and James W.T., (2001), Communication Theories; Origin, Methods, and Uses in the Mass Media”, Fifth Edition. University of Texas at Austin: Addison Wesley Longman Inc.

Wood, J.T., (2000), Communication Theories in Action", California: Belmont. 